\title{
ヒマワリ矮性品種を用いた茎の伸長に対する ジベレリンの効果を理解するための教材開発
}

\author{
園山 博 ${ }^{1}$ \\ 渥美 茂明 ${ }^{2}$
}

\begin{abstract}
【要約】
高性品種と矮性品種のヒマワリ（Helianthus annuus）を播種して 12 日目に芽生えの草丈 を比較すると, 矮性品種「小夏」の草丈は高性品種「かがやき」の草丈の約 $20 \%$ しなかっ た。また, 矮性品種の播種後 5 日目の芽生えに $1.0 \times 10^{-4} \mathrm{M}$ の $\mathrm{GA}_{3}$ 溶液を投与すると, 播種後 12 日目（投与後 7 日目）には，草丈が対照の 2 倍以上となった。この間の平均伸長速度は, $7.6 \mathrm{~mm} /$ 日であり, 無処理の高性品種の平均伸長速度 $8.0 \mathrm{~mm} /$ 日とほぼ同じ值となった。す なわち, 矮性品種の芽生えは, 投与したジベレリンに応答し, 高性品種の伸長成長速度まで 回復した。これらの結果に基づき，高性品種と矮性品種の芽生えにジベレリンを投与し，節 間の伸長を 1 週間にわたり測定する生徒実験を行なった。ワークシートを用いて，生徒たち に草丈の変化のグラフを作成させた。さらに, 草丈伸長の差異を品種や処理区の間で比較し, 草丈の違いとジベレンとの関係を考えさせた。この実践の前後に学習の理解を評価したとこ ろ，生徒たちは品種の違いとジベレリンとの関係に関する問いに対して，正答を選択する割 合が $57 \%$ から $86 \%$ へ，有意に上昇した。アンケートでは $95 \%$ の生徒が, 植物の成長の仕 組みに興味を持てたと回答した。また，品種間の草丈の違いとジベレリンの関係を深く調べ る方法を問うと，ジベレリン量の測定や遺伝子の操作をあげた生徒が見られ，多くの生徒が 品種別にジベレリンの生産量を測定することを考えたり，一部にはその原因となる遺伝子に ついて考えたりするようになった。
\end{abstract}

[キーワード］矮性，ジベレリン，ヒマワリ，実験教材

\section{1.はじめに}

現行の学習指導要領解説 (文部科学省, 2009) で は, 植物の環境応答の単元の内容の取扱いに「植物 ホルモンと光受容体を扱うこと」と明示している。 一方, 旧学習指導要領解説 (文部省, 1999) の内容 の取扱いでは「植物の発芽, 成長, 花芽形成等と環 境との関連について探究の過程を重視して扱うこと」 と記載してあり, 植物ホルモンという文言は見当た らない。現行では, より明確に植物ホルモンの学習 を行なうことが示された。また, 現行学習指導要領 に基づく各教科書（浅島ら，2013；本川ら，2013； 嶋田ら, 2013 ; 吉里ら, 2013 ; 庄野ら, 2014）には, 旧課程の教科書（石原ら, 2009 ; 石川ら, 2008 ; 川

\footnotetext{
${ }^{1}$ 京都府立山城高等学校

${ }^{2}$ 兵庫教育大学大学院教育内容. 方法開発専攻
}

嶋ら，2011；本川ら，2006；田中ら，2009）で扱わ れたオーキシン，ジベレリン (以下 GA と示す), ア ブシシン酸, サイトカイニン, エチレンの 5 つの植 物ホルモンに加え, ジャスモン酸やブラシノステ ロイドも扱われる内容へと変更された（表 1$)$ 。し かし, 探究活動は, 旧課程から現課程に変わっても オーキシンの作用を扱うものが多く，新しい内容の 実験は見られない(表 2 )。

この単元で実践される実験が少ないことは, 山路 ら（2006）の調査で示されている。彼らは, 高等学 校で生物を履修した者を対象に生物 I A, 生物 I B および生物 II の教科書に掲載されている 34 の実験を 行なった経験の有無を調査した。植物ホルモンに関 わる実験は，34 項目中 25 番目となる $11.9 \%$ 者し か経験がなかった。

近年, 植物ホルモンの作用と信号伝達などの多く 
の事像が, 変異体を利用し解明されている。例えば, 根の異常な重力屈性を示すシロイヌナズナの変異体 $a u x 1$ を用いたオーキシン輸送体タンパク質の発見 (Marchant ら, 2002) や, シロイヌナズナの GA に対 する不感受性の変異体 gai を用いた GAの信号伝達経 路の解明（Peng ら, 1997）がある。

実験植物の変異体は, 研究機関で系統の維持管理 が行われており, 高等学校では, 入手や利用が困難 である。しかし, 園芸植物には, 矮性変異体が有用 な品種として販売されている場合がある。GA が関わ

\section{表 1 現旧学習指導要領に基づく各教科書に記載のある 植物ホルモン}

\begin{tabular}{|c|c|c|c|c|c|c|c|c|}
\hline & & Aux & GA & CK & ABA & Eth & BS & $\mathrm{JA}$ \\
\hline \multirow{2}{*}{$\mathrm{D}$ 社 } & 現 & 0 & 0 & $\bigcirc$ & 0 & 0 & 0 & 0 \\
\hline & 旧 & 0 & 0 & 0 & 0 & 0 & & \\
\hline \multirow{2}{*}{$\mathrm{J}$ 社 } & 現 & 0 & 0 & 0 & 0 & 0 & 0 & \\
\hline & 旧 & 0 & 0 & 0 & 0 & 0 & & \\
\hline \multirow{2}{*}{$K$ 社 } & 現 & $\bigcirc$ & 0 & 0 & 0 & 0 & 0 & 0 \\
\hline & 旧 & 0 & 0 & 0 & 0 & 0 & & \\
\hline \multirow{2}{*}{$S$ 社 } & 現 & 0 & 0 & 0 & 0 & 0 & & \\
\hline & 旧 & 0 & 0 & 0 & 0 & 0 & & \\
\hline \multirow{2}{*}{$\mathrm{T}$ 社 } & 現 & 0 & 0 & 0 & 0 & 0 & 0 & 0 \\
\hline & 旧 & 0 & 0 & 0 & 0 & 0 & & \\
\hline
\end{tabular}

Aux : オーキシン, GA：ジベレリン, CK : サイトカイニン, $\mathrm{ABA}$ : アブシシン酸, Eth : エチレン, $\mathrm{BS}$ : ブラシノステ ロイド, JA：ジャスモン酸
る矮性形質の要因には, GA 生合成系の変異や GAに 対する不感受性の変異を挙げることができる（山根, 1991）。生合成系の変異ならば，GAを投与すれば矮 性形質が改善され，茎の伸長が確認できる。

大手種苗会社のホームページ（例えば, サカタの タネ (http://www.sakataseed.co.jp/)）で調べると， ス イートピー, コスモス, ヒマワリなどの矮性品種を 見つけることができる。スイートピーやコスモスは, 茎が細く, 節間長を繰り返し測定する際に折ってし まう心配があるが, ヒマワリは幼苗でも茥が十分に 太く, 繰り返しの測定が可能であると期待される。 種子袋の記載には, ヒマワリの高性品種「かがやき」 は草丈が約 $160 \mathrm{~cm}$ もあるが, 矮性品種「小夏」の草 丈は 25〜30 cm と低い。また, ヒマワリは花壇にも よく植えられている身近な植物でもあり, 生徒たち の興味を引き付けるものと期待される。

現行の高等学校「生物」の教科書 5 社中 3 社には, GA の説明と合わせ黒田栄一氏が発見者であることが 記載されている（表 3$)$ 。日本人研究者が発見したこ とや種なしブドウの生産に利用される等の話題があ り, GA は生徒に興味を持たせる話題の多い植物ホル モンである。

エンドウを材料に GA とわい化剤を用いて草丈の 伸長を測定する実験が $\mathrm{K}$ 社の教科書に揭載されて いる（表 2)。投与の成否など外的要因に草丈が左 右されるわい化剂を用いた実験よりも，矮性品種を

\section{表 2 現旧学習指導要領に基づく各教科書で扱う探究活動の植物ホルモン関連実験}

\begin{tabular}{|c|c|c|c|c|c|c|c|}
\hline テーマ & 活動内容 & 植物ホルモン & $\mathrm{D}$ 社 & J社 & $\mathrm{K}$ 社 & $\mathrm{S}$ 社 & $\mathrm{T}$ 社 \\
\hline 屈光性 & $\begin{array}{l}\text { 子葉鞘の先端から } 5 \mathrm{~mm} \text { 接きに印をつけ，暗室中で一 } \\
\text { 方から光を当てたときの変化を測定する。 }\end{array}$ & (Aux) & & 0 & & & \\
\hline オーキシンの働き & $\begin{array}{l}\text { 子葉鞘を } 1 \mathrm{~cm} \text { に切り, 濃度の異なるオーキシンに浸し, } \\
\text { その後の長さを調べる }\end{array}$ & Aux & & & & () & \\
\hline $\begin{array}{l}\text { オーキシンによる } \\
\text { 屈曲 }\end{array}$ & $\begin{array}{l}\text { マカラスムギの子葉鞘に濃度の異なるオーキシンにつ } \\
\text { けその後の屈曲する角度を測定する。 }\end{array}$ & Aux & & 0 & & & \\
\hline $\begin{array}{l}\text { ジベレリンによる植 } \\
\text { 物の成長調節 }\end{array}$ & $\begin{array}{l}\text { エンドウにジベレリンやわい化剤を与え茎の伸長を調 } \\
\text { ベる内容 }\end{array}$ & GA & & & () & & \\
\hline $\begin{array}{l}\text { 光と植物ホルモンが } \\
\text { 発芽に及ぼす影響 }\end{array}$ & $\begin{array}{l}\text { レタス種子を用いて, 暗箱下, 蛍光灯其々でジベレリ } \\
\text { ン, アブシシン酸を添加することによる発芽率の違い } \\
\text { を測定する。 }\end{array}$ & $\mathrm{GA}, \mathrm{ABA}$ & & ○ & & & \\
\hline \multirow{2}{*}{$\begin{array}{l}\text { エチレンが植物に与 } \\
\text { える影響 }\end{array}$} & $\begin{array}{l}\text { 成熟した果実とともに未熟な果実や樹木の枝を入れ, } \\
\text { 果実の色の変化や落葉を調べる。（成熟果実からの Eth } \\
\text { を予想） }\end{array}$ & (Eth) & $\bigcirc$ & & & & $\bullet$ \\
\hline & $\begin{array}{l}\text { 密封容器にアズキの芽生えにとリンゴを置き胚軸の伸 } \\
\text { 長が阻害されることを調べる。（成熟果実からの Eth } \\
\text { 予想） }\end{array}$ & (Eth) & & & & & 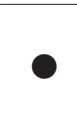 \\
\hline
\end{tabular}

旧課程の教科書に揭載されているものはの，旧課程，現課程ともに掲載されている実験は○，現課程のみに揭載されている ものは○で示した。 
表 3 各教科書におけるジベレリンの学習項目

\begin{tabular}{|c|c|c|c|c|c|}
\hline & $\mathrm{D}$ 社 & J 社 & $\mathrm{K}$ 社 & $\mathrm{S}$ 社 & $\mathrm{T}$ 社 \\
\hline 矮性 ${ }^{1)}$ & & & $\triangle$ & & \\
\hline 抽苔 ${ }^{2)}$ & & & 0 & 0 & \\
\hline セルロース ${ }^{3)}$ & 0 & 0 & O & & 0 \\
\hline 馬鹿苗病 & & 0 & & 0 & 0 \\
\hline 研究者 & & 0 & & 0 & 0 \\
\hline 発芽 & 0 & 0 & 0 & 0 & 0 \\
\hline 種なしブドウ & 0 & 0 & 0 & & 0 \\
\hline
\end{tabular}

1) 矮性という言葉を用いてないが，K 社では，メンデルが 取り上げたエンドウが草丈の「低い」形質と紹介してい る。 ${ }^{2)}$ 抽苔は，ジベレリンにより，ロゼットから茎が伸長

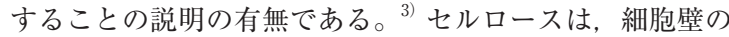
セルロース纎維の配向とジベレリンの作用を扱っているか である。それ以外の項目は，それぞれについての紹介とジ ベレリンの関倸の説明の有無を示した。

用いた方が材料の準備が簡便である。遺伝的な矮性 では，草丈が安定して低い苗を多量に用意でき，生 徒実験に適していると考えられる。また, 矮性品種 は農業上の有用品種であり, いわゆる緑の革命の主 役となったメキシコ系短稈コムギ品種群やイネの高 収量品種 IR8 などは代表的な矮性品種である（山 根, 1991）ため, 矮性品種は, 学習内容と実社会で の利用を関連付ける好材料である。さらに，品種の 違いから, 遺伝子の違いへと発展的に扱うことも期 待できる。ent-カウレン酸酸化酵素遺伝子の欠損に よる矮性ヒマワリ品種も知られている（Fambrini ら, 2011)。

そこで，本稿では，ヒマワリの高性品種と矮性品 種の GA および GA 合成阻害剤に対する反応特性を 調べ，通常の設備で実施可能な植物ホルモン（GA） の作用を実験的に調べる教材開発を試みた。また, この教材を用いた実践授業の前後に評価問題を生徒 に課し，実践の効果を調查した。

\section{2. 教材と利用するための諸実験}

\section{1 材料の準備と節間の測定}

ヒマワリ (Helianthus annuus L.) は，ホームセン ターなどで販売されているサカタのタネ（横浜市） の矮性品種「小夏」と高性品種「かがやき」を用い た（これらの品種を選択した特段の理由はない）。直 径 $7.5 \mathrm{~cm}$ のポリエチレン製育苗ポットに培養土（夕 キイ種苗）を入れ，その中央に深さ $2 \mathrm{~cm}$ 程度の穴 をあけ，種子を 1 粒ずつ播種した。十分に吸水させ た育苗ポットを蛍光灯で照度約 5000 lux, 明暗周期 $14 ： 10$ に設定した温度 $25 \pm 1^{\circ} \mathrm{C}$ の恒温装置（日本医 化器械製作所 LH-100-RD）内に置いた。3-4 日経過

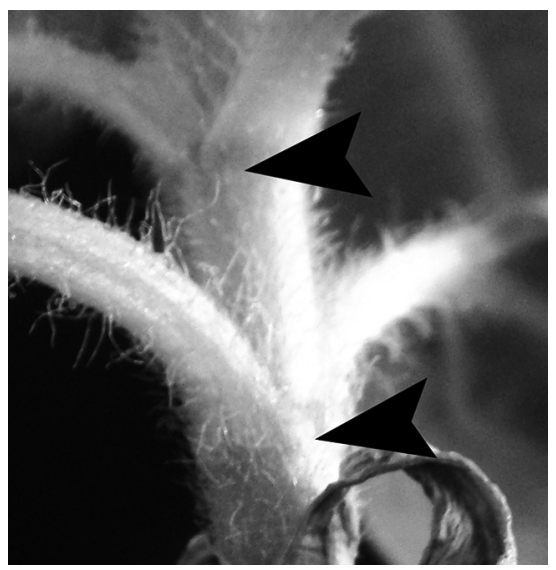

図 1 節間の測定部位

節間は葉の基部を始点（矢頭下）として，ひとつ上位に ある葉の基部（矢頭上）までの長さとした。この部分に 物差しをあて長さを測定した。

すると芽生えが生じ，子葉が展開した。

$0.17 \mathrm{~g}$ の $\mathrm{GA}_{3}$ （和光純薬）を約 $0.5 \mathrm{~mL}$ の $1 \mathrm{M}$ の $\mathrm{NaOH}$ に溶かし，イオン交換水を加え $500 \mathrm{~mL}$ に希釈 し $1.0 \times 10^{-3} \mathrm{M}$ の溶液とした後, $1 \mathrm{M}$ の $\mathrm{HCl}$ で $\mathrm{pH}$ を 7.0 に調整した。さらに 10 倍に希釈して $1.0 \times 10^{-4} \mathrm{M}$ として使用した。GA 合成阻害剤としてウニコナゾー ル $\mathrm{P}\left(\mathrm{C}_{15} \mathrm{H}_{18} \mathrm{ClN}_{3} \mathrm{O}\right)$ を $0.025 \%$ 含むスミセブン $\mathrm{P}$ 液 剂（住友化学）をイオン交換水で 10 倍に希釈して使 用した。ウニコナゾールは，GA 合成系の初期段階で ある ent- カウレン酸の合成に際し C19 位の酸化的脱 メチル化を阻害する（Katagi ら，1987）。各薬剤はポ ンプ式スプレー（大創産業）に入れ，茎頂部分に向 けて 3 回噴霧して約 $0.4 \mathrm{~mL}$ を投与した。

1 つの試料を繰り返し測定するために，傷つけな いように，培土表面から子葉の付け根まで（肧軸長） と葉柄の茎への付け根の部分を始点として, 一つ上 位の葉の付け根まで（節間長）を測定した（図 1)。 この肧軸長と各節間長との総和を草丈とした。

\section{2 矮性, 高性ヒマワリの成長と GA の作用}

矮性品種も高性品種も播種後 3 日で発芽し, 子葉 を展開した。高性品種は子葉展開後も肧軸の伸長が 続くが，矮性品種では肧軸はさほど伸びずに本葉を 作り，各節間は，その後もほとんど伸長することが なかった。播種後 5 日目（発芽後 2 日目）では, 矮 性品種の草丈は高性品種の約 30\%, 播種後 12 日目 には，約 20\%しかなかった（図 2)。

播種後 5 日目に, 子葉が展開した矮性品種の芽生 えに GAを投与した後, 草丈を繰り返し測定した。 
投与 2 日目から草丈に明瞭な差が生じた。GAを投与 した芽生えの草丈は, 6 日目には対照の 2 倍以上の 長さなった（図 2)。 $\mathrm{t}$ 検定の結果, GA 投与株の草丈 の平均值は対照に比べ有意に大きかった $(p<0.05)$ 。

播種後 5 日目以降の草丈の值を用いて回帰直線を 求めると無処理の高性品種の傾きは $8.0 \mathrm{~mm} /$ 日とな り, GA 投与の矮性品種の傾きは $7.6 \mathrm{~mm} /$ 日とほぼ同 じ值となった（図 2)。つまり, 矮性品種は GA の極 端な不足状態にあり, 投与した GA は高性品種の成 長と同レベルに回復するだけの十分な量であったと 考えられる。

部位別の伸長を調べたところ, 肧軸の伸長には大

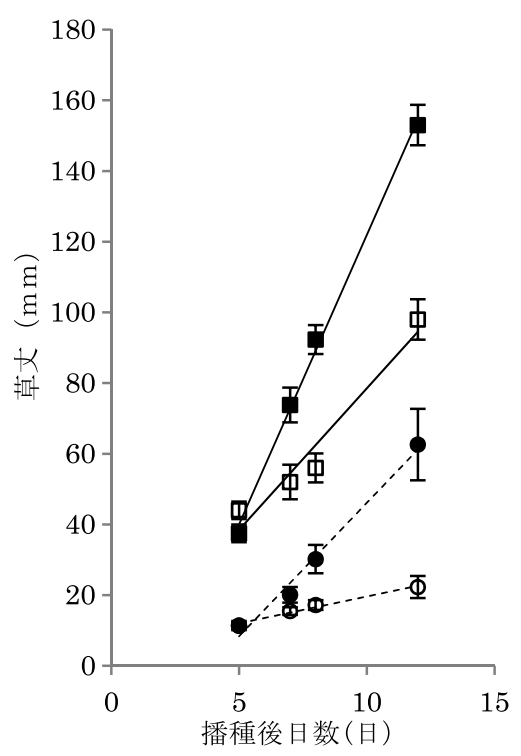

図2 ヒマワリ芽生えの草丈の変化

播種後 5 日目からの各品種の草丈の推移の平均值をプ ロットし, 回帰直線を求めた。高性品種の対照区（ $\square)$ は傾き $8.0, \mathrm{r}^{2}=0.95, \mathrm{GA}$ 投与区（回）は傾き $16, \mathrm{r}^{2}=$ 0.99 , 一方, 矮性品種の対照区（○）は傾き $1.5, \mathrm{r}^{2}=$ 0.98, GA 投与区（○）は傾き 7.6, $\mathrm{r}^{2}=0.98$ となった。 傾きは $\mathrm{mm} /$ 日を, $\mathrm{r}^{2}$ は決定係数を,バーは SE を示す。

きな差は見られず, 処理後 6 日目の平均の胚軸長に は有意な差はなかった $(p>0.05)$ (図 3A)。対照の 第 1 節間は 4 日目以降ほとんど伸長しなかったが, $\mathrm{GA}$ 投与区の第 1 節間は実験期間中伸長し続け，6 日 目には投与区の第 1 節間は対照の約 6 倍となってい た（図 3B）。第 2 節間は, GA 投与後 6 日目に伸長 を始めたが, 対照の節間はまだ伸長していなかった (図 3C)。
播種後 10 日目の矮性品種の芽生えへの GA の投与 は, 播種後 5 日目での投与と全く異なり, 第 1 節間 は全く伸長せずに（図 4A），第 2 節間と第 3 節間が, それぞれ，投与の翌日に，あるいは，投与 3 日目に 伸長を開始した。さらに，投与 8 日目には，投与し た植物の第 2 節間は対照の約 3 倍（図 4B），第 3 節 間では約 5 倍に伸長した（図 4C)。つまり，GAを播 種 5 日目の矮性品種の芽生えに投与すると, 第 1 節 間の伸長が顕著であり，一方，播種後 10 日目に投与 すると，第 2 節間やそれに続く第 3 節間の伸長が著 しかった。GAは，伸長した節間をさらに伸長させる のではなく，これから伸長する節間の伸長に作用し， より伸長させていると考えられる。さらに，各節間 は伸長とともに GA 感受性を失い, 投与された外生 GA に反応しなくなったと考えられる。

矮性品種「小夏」に GA を投与すると感受性を持 つ節間が伸長して草丈が伸びた。従って, この矮性 品種は, GA に対して常時不感受でなく, GA 不足に よる矮性であることが示唆される。一方, 草丈の高 い高性品種は常時 GA を生産しているため節間の伸 長が大きいと考えられる。このことを確かめるため に, 播種後 5 日経過し子葉を展開した高性品種「か がやき」の芽生えに GA 合成阻害剂を投与すると, 第 1 節間の伸長は，10日目で対照の約 $35 \% ， 17$ 日 目では対照の約 $25 \%$ に著しく抑制された。しかし, $\mathrm{GA}$ 合成阻害剂投与後 10 日目に GA を投与すると, 胚軸の伸長促進は見られないが（図 $5 \mathrm{~A}$ ), 第 1 節 間では伸長が再開し，GA 投与 7 日目で，対照の約 85\%に回復し，GA 投与をしなかった節間の約 4 倍の 長さに伸長した（図 5B）。第 2 節間ではさらに伸長 し, GA 投与 7 日目で, 対照の 4 倍以上の長さとなっ た（図 5C)。つまり，「かがやき」は内生 GA を常時 生成し, 感受性がある時期に節間が伸長する成長を 示すと考えられる。

\section{3. 授業実践}

\section{1 生徒実験の方法}

実施適期は，ヒマワリを野外栽培するなら，5-7 月であり, 人工気象器があれば通年の実施が可能で ある。材料として, 高性品種と矮性品種のポット苗 を各班に 2 株ずつ用意し, 50 分の授業を 1 週間の間 隔で 2 回行なう計画を立案した。

1 回目の授業では, 各苗の節間長の測定と, 品種 ごとに GA 投与区を設定するように指示する。投与 区には，生徒たちが芽生えの茎頂部にポンプ式スプ レーを用いて, $1.0 \times 10^{-4} \mathrm{M}$ の GA を約 $0.4 \mathrm{~mL}$ 噴霧す る。残りには投与せず対照とする。処理後, これら 

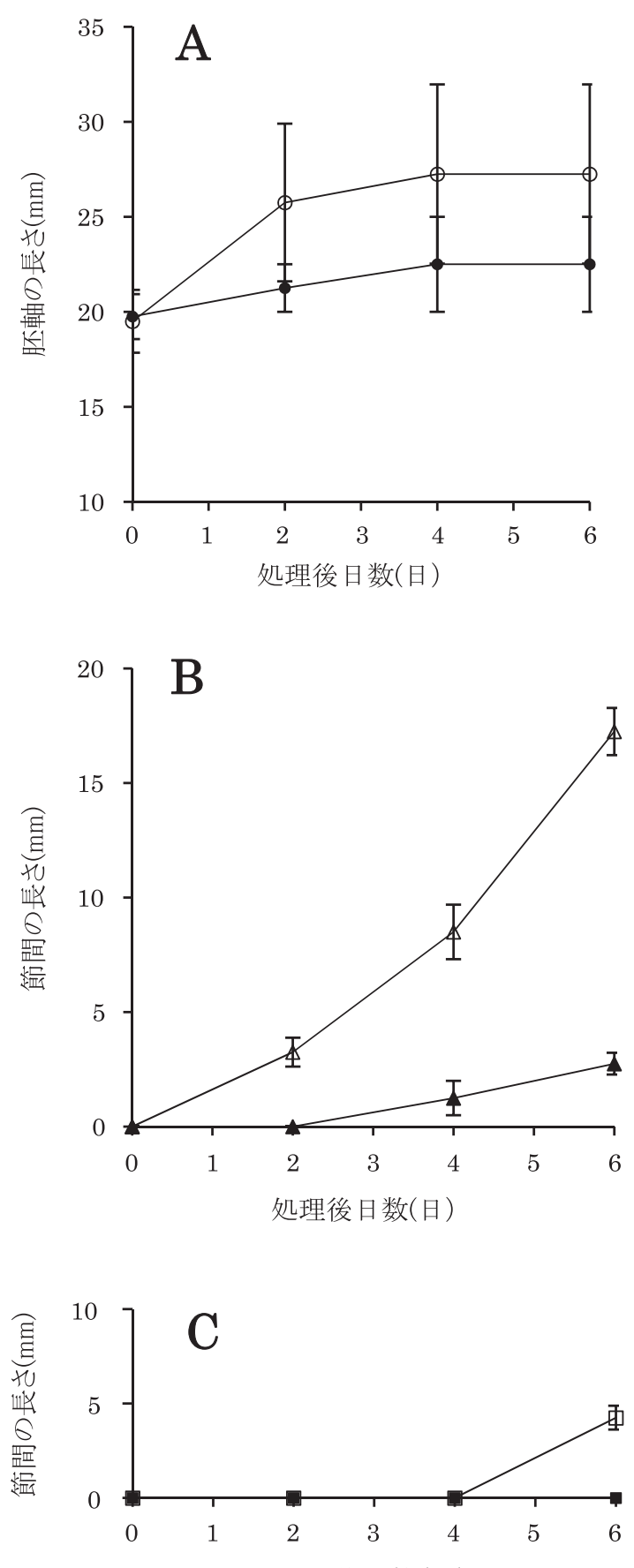

処理後日数 $($ 日)

図 3 播種後 5 日目の矮性ヒマワリの芽生えに $\mathrm{GA}_{3}$ を 投与した後の節間長の変化

播種後 5 日目の矮性ヒマワリの芽生えに $1.0 \times 10^{-4} \mathrm{M}$ の $\mathrm{GA}_{3}$ を投与した後の肧軸 (A), 第 1 節間 (B), 第 2 節 間 $(\mathrm{C})$ の長さの変化を表した。白抜きマークは $\mathrm{GA}_{3}$ 投 与した時の変化を, 黒塗りマークは対照を, バーは SE を示している。
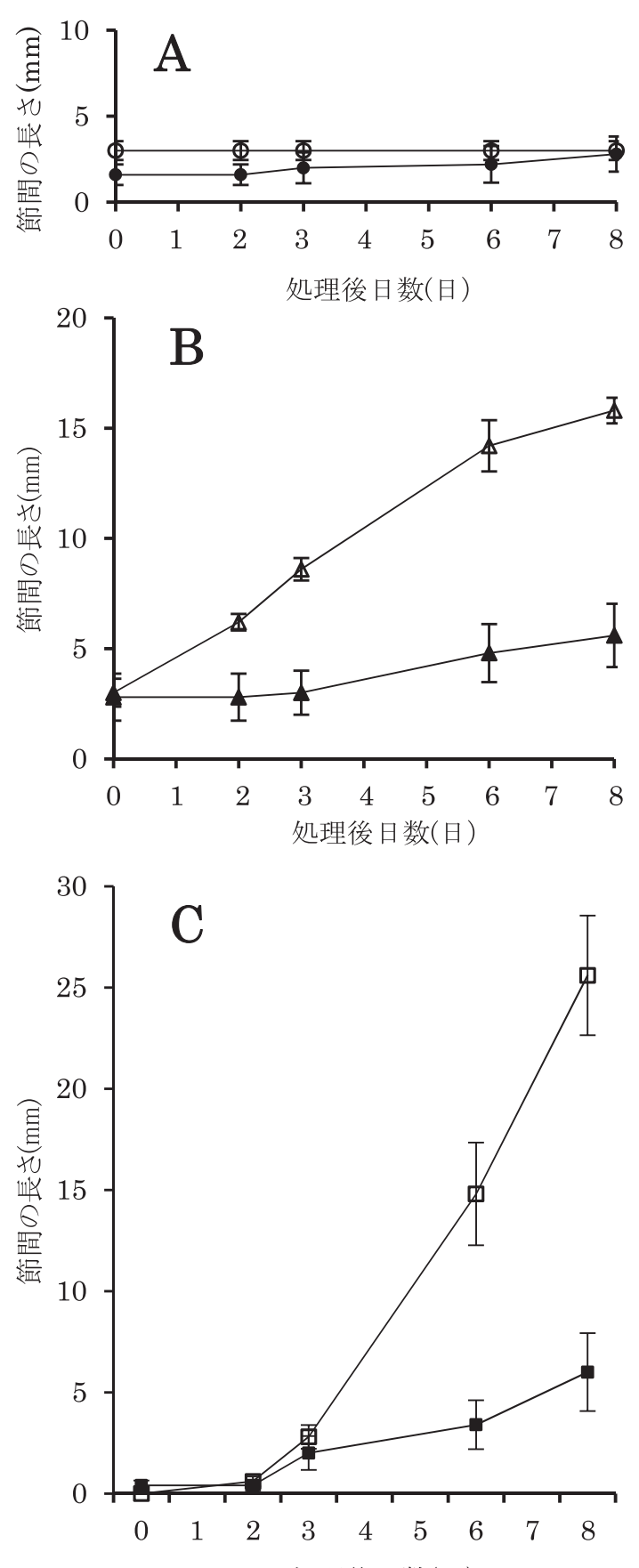

図 4 播種後 10 日目の矮性ヒマワリの芽生えに $\mathrm{GA}_{3}$ を 投与した後の節間長の変化

播種後 10 日目の矮性ヒマワリの芽生えに $1.0 \times 10^{-4} \mathrm{M}$ の $\mathrm{GA}_{3}$ を投与した後の第 1 節間 $(\mathrm{A})$ ，第 2 節間 $(\mathrm{B})$ ，第 3 節間 $(\mathrm{C})$ の変化を表した。白抜きマークは $\mathrm{GA}_{3}$ 投与時 変化, 黒塗りマークは対照を示す。バーは SEを示して いる。 
の苗を日当たりのよい空際（もしくは, $25^{\circ} \mathrm{C} に$ 設定 した人工気象器内）に置くように指示する。これら の作業に当たり生徒たちに与えるべき注意点は, 茎 を粗暴に扱い折らないこと, 物差しを直接茎に当て 長さを測定すること, そして, 茎頂部分に GA 溶液 が確実にかかるようにスプレーで噴霧することであ る。さらに, 土の表面が乾けば水やりすること, そ して, 1 週間各節間の伸長を毎日測定することを指 示する。

各品種のヒマワリを「ミニヒマワリの小夏」と 「普通のヒマワリのかがやき」と呼び分けたが, 観察 により違いに気付くことを期待して, その詳細は説 明しなかった。

1 週間後の 2 回目の授業では, 教師はワークシー 卜を用いた結果のまとめを指導する。ワークシート は 4 つの実験区の結果を記入するグラフ用紙と各実 験区を比較して伸長の違いを記入する欄を設けてあ り，まとめとして，「GAはどのような働きがあると 分かりましたか」と「ミニヒマワリと通常のヒマワ リは何が違うため形態の変化に差があると考えられ ますか」という問いを設け, 自由記述で回答を求め る。このワークシートに各班の測定結果を記入させ, 班で意見を出し合いながら各項目に答えるよう指示 する。

\section{2 生徒実験の結果と考察}

以上の計画に沿って, 平成 27 年 6 月 9 (火) か らの 1 週間, 京都府立 $\mathrm{Y}$ 高等学校にて, 3 年の生物 選択クラス 21 名（男子 12 名女子 9 名）を対象に 授業実践を行った。このクラスでは T 社の教科書の 環境と植物の応答の学習を終えていたので, 植物ホ ルモンの名称やその働きは既習事項である。この単 元のまとめとして実験を実施した。1回目の授業で の作業において, 植物の栽培実験が小学校以来の取 り組みの生徒もいて, 生徒の会話や苗の取扱いから 興味を持って行なっていると感じられた。測定時刻 は特に指定しなかったが, 班により昼休みであった り，放課後であったり時間は異なるがそれぞれ役割 を決め定時に測定した。芽生えの先端の未伸長部分 の扱いは特に説明をしなかったので, 生徒たちも未 伸長部分は無視した。2 回目の授業において, 最終 回の測定を行なった後, 班ごとに 1 週間分のデータ をグラフ化した。各班の值は大きく異なることはな く, 全班の值を平均して求めたグラフにおいても標 準誤差は小さかった（図 6)。考察中に机間巡視をす ると, GA 投与の有無の比較は容易に行えていたが, 品種の違いと GA の関連を考えるのには苦労してい
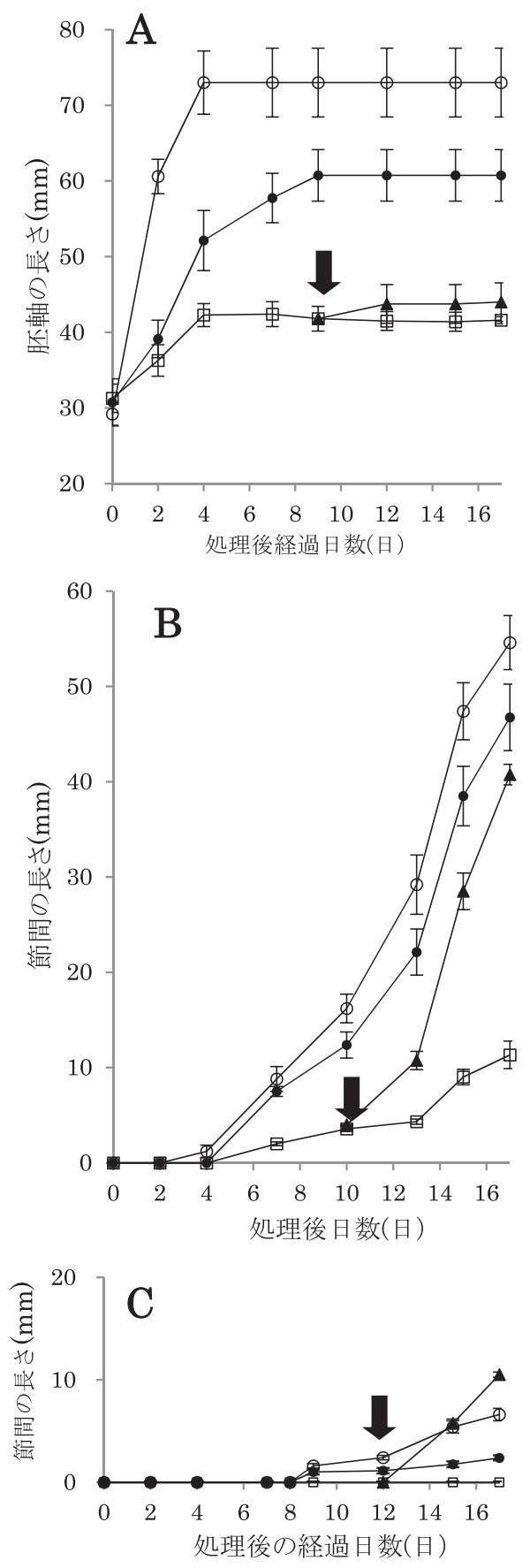

図 $5 \mathrm{GA}_{3}$ や $\mathrm{GA}$ 合成阻害剤投与後の高性ヒマワリの節 間伸長

播種後 5 日後の高性ヒマワリに, ジベレリン $\left(\mathrm{GA}_{3}\right)$ や $\mathrm{GA}$ 合成阻害剂を投与 (0日) 後, 胚軸 (A) ・ 第 1 節間 (B) ・ 第 2 節間（C）の伸長を測定した。GA 合成阻害剂処 理後 10 日目に $1.0 \times 10^{-4} \mathrm{M}$ の $\mathrm{GA}_{3}$ を投与した (矢印)。GA 投与区 $(\bigcirc), \mathrm{GA}$ 合成阻害剂投与 $(\square)$ 。阻害剂投与後の $\mathrm{GA}$ 投与 (ム)。は無処理（対照），バーは SE を示す。 
る様子が見られた。班内で相談することと品種の形 態的な違いと GA の働きが何であったかを思い出し， GA が㗢けば形態の特徴にどう関わるかを考えるよ うにアドバイスすると，生徒たちは，互いの意見を 出しながら考えをまとめられるようになった。アン ケートの「実験の作業はわかりやすかったですか。」 や「実験の内容は分かりやすかったですか。」「荷A の働きを理解できましたか」の各問いに対し，「とて もそう思う」，「そう思う」を合わせると約 $100 \%$ と なった（表4）ので, 生徒たちは, 納得のできる学 習を行なったと自己評価したとみられる。一方, 全 ての矮性形質は GA 量不足によるものではないので, 生徒が誤認識しないように補足説明をする必要が ある。

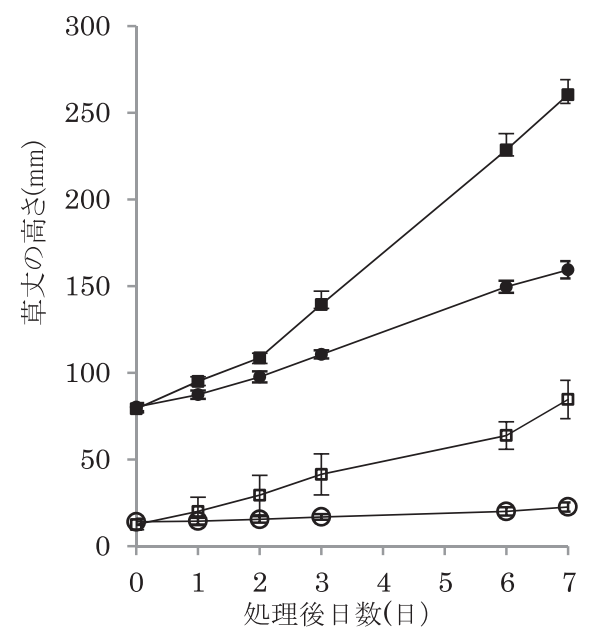

図 6 生徒実験の結果

肧軸と各節間の長さの合計を草丈として表した。值は, クラスの全測定值の平均值である。高性品種（無処 理), 高性品種 (GA 投与), ○矮性品種 (無処理), $\square$ 矮性品種（GA 投与), バーは SE を示す。

\section{4. 実践授業の評価}

\section{1 評価の調查方法}

本教材を用いた授業の効果を客観的に評価するた め, 5 つの選択肢から 1 つもしくは複数の正しい説 明文を選ぶ評価問題を事前と事後の 2 回実施し, 回 答の変動を調べた（表 5)。事前は，授業に入る直前 に行ない。事後は, 実験結果の解説後に行なった。 アンケートは持ち帰らせ, 翌日に回収した。

\section{2 評価問題及びアンケート結果と考察}

設問 1 は，学習事項である GA の作用が定着して いるかを測ることを目的とした問いである。対象の クラスは, この内容が既習事項であるため, 知識 が定着していれば，（a）を容易に選択できる。この 設問に対する生徒の答えは，事前，事後とも全員が （a）を選択しており，実験の実施による影響は見ら れないが，基礎的な知識が定着している学習集団で あったと考えられた。

設問 2 は，注意深く観察したかを問う設問である。 実験では GAを 1 回しか投与していないため, 作業 を行なえば，容易に（d）を選択できる。実験後の 正答に有意差が生じたため（表 5)，実験の効果があ ると言える。一方，変化が生じたる時期は，（a）と （b）と分かれた結果となり，実験後の正答に有意差 は生じなかった（表 5)。矮性品種に GA を投与する と対照より草丈が, 2 日目には平均約 $12 \mathrm{~mm}$ 長く伸 長し，3 日目では平均約 $25 \mathrm{~mm}$ 長い結果が得られた。 2 日目からの草丈の違に気づくと考えたが，より大 きな差がつく（b）を選択した生徒の割合も増えた。 測定結果をよく吟味することなく回答を選んだ生徒 が一部にいたことは，測定結果をグラフ化する作業 段階で，違いが生じる日数に着眼する指導の必要性 が示唆されたと考えられる。

設問 3 は，実験結果より導き出される事実を問う 設問である。生徒が実験を通して正しく GA の効果 を理解し，GA が茎の伸長を促進すると理解できれ ば，容易に（a）と（d）を回答できる。（a）（d）い

表 4 授業に対するアンケート結果

\begin{tabular}{lcccc}
\hline \multicolumn{1}{c}{ 設問内容 } & とてもそう思う & そう思う & そう思わない & 全くそう思わない \\
\hline 実験の作業はわかりやすかっだすか。 & 52 & 48 & 0 & 0 \\
\hline 実験の内容はわかりやすかったですか。 & 48 & 48 & 0 & 5 \\
\hline ジべレリンの働きは理解できましたか。 & 48 & 48 & 5 & 0 \\
\hline 品種の違いは何によるものか理解できましたか。 & 10 & 52 & 33 & 5 \\
\hline 植物の成長の仕組みに興味か持てましたか。 & 38 & 57 & 0 & 5 \\
\hline 実験を行うことで, 理解は深まりましたか。 & 48 & 48 & 0 & 5 \\
\hline
\end{tabular}

各設問について 4 件法で調査した結果を\%で示している。 
ずれも実験後の正答に有意差が生じたことから（表 5)，実験を通して，品種間の形質の差が生じた理由 を考えることができたと考えられる。

設問 4 は, 実験操作の意味が理解できているかを 問う設問である。事後での正答者の変動に有意差は 認められなかった（表 5), 誤答である（d）を正答 と選ぶ者が増加する結果となった。生徒たちは, 実 験結果より GA が節間の伸長を促進する効果をもた らしたと読み取ったと考えられる。しかし，GAの 作用は，発芽の促進や子房の肥大にも関わると既習 事項にあるため, 茎に特定するのではなく, 種子や 子房にも働きかけると考えて（d）を選択しないと想 定していた。（d）を選択する生徒が増加したことは, 実験結果に強く囚われた生徒が多くいたことの現れ であると考えられる。一方，(c) を誤りとする理由 は無い。GA 溶液はヒマワリの草丈を伸長させるこ とを実験で学んだが, ブドウの果実を肥大させるこ とも既に学んでいたため（c）を選択すると考えてい た。評価問題の文言にも工夫が必要だったと考えら れる。

設問 5 は, 実験で扱った内容ではなく, 通常の授 業で扱う一般的な植物ホルモンの働きを問う設問で ある。この設問で正答を選択する割合が上昇すれば, 本実験やレポート作成を通して, 植物ホルモンの働 きを振り返ることや思い出したことが現れたと考え られる。(b) のオーキシンに関することと（e）の GA に関することが正答であるが, 事後での正答者の 変動は，（b）について有意差は認められなかったが, （e）について有意差が認められた（表 5)。GA は本 実験で扱った植物ホルモンであるので関心を持ち, 既習事項を思い起こせたが, それ以外の植物ホルモ ンまで興味が深まらなかったと考えられる。

また, 考察問題として「ミニひまわりと通常のヒ マワリでは何が違うために形態的な変化に差がある と考えられますか。という設問 (自由記述) に対し て,「植物自身が生産する GAの量が違うからだと思 う」といった GAの量の違いに着目した回答が全体 の約 $80 \%$ であった（図 7)。本教材を用いて，「GA は 草丈を大きくする」という仮説を肯定する結果を得 た（図 6)。ここから, 生徒たちの多くは, 「植物は 自ら GA を作り背を高くしている。」「少ししか作 れないと背が低くなる」という仮説に至ったと考え られる。本実験ではこれらの仮説の立証をしていな いが，生徒たちに考察問題で答えた内容を確かめる 実験を質問すると, GA を与える場所や量を変えるな どの GA 投与実験や GA 量の測定実験を行うなどの GAに関わる実験を想定した生徒が多く見られた（図

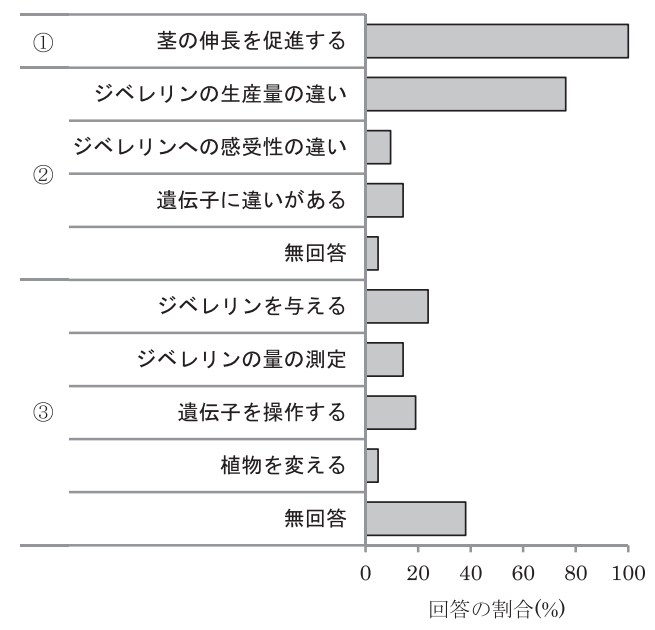

図 7 設問（自由回答）に対する回答の割合

(1)「ジベレリンはどのような働きがあると分かりました か。」(2)「ミニヒマワリと通常のヒマワリは何が違うた めに形態の変化に差があると考えられますか。」(3)「(2) で考えたことを証明するためにほかにどんな実験をすれ ば良いと考えられますか。」のそれぞれの問いに対する 回答（自由記述）の割合。(1)に対しては全員が茎の伸長 に関係すると答えた。(2)に対しては，ジベレリンの生産 量に着目した回答が多かったが，感受性に関する回答も あった。(3)では遺伝子に着目した意見も見られた。回答 者の総数は 21 名であった。

7）。このような意見は, 今回行なった生徒実験で得 た植物の草丈に関して GA が主要な働きを担ってい るという認識を持ったことを示している。GA 量の測 定は，高等学校では難しいが，GA 合成阻害剤の投与 実験（図 5）は，生徒実験として行なうことが可能 である。今後は, このような実験を組み立て, 生徒 たちの考えを立証させることも含む教材に発展させ たい。一方, 考察問題の回答の中には, GA 量の違い に言及しているものだけでなく，GAの感受性に差 があるという考えを述べた生徒もいた。矮性品種に GA を投与することで伸長が回復し（図 2)，GA 合成 阻害剂を投与すると節間の伸長は抑えられるが，GA を投与すると再び伸長が促進されるため（図 5)，本 研究で使った品種の矮性形質は GA の感受性に由来 するものではない。内生 GA 量の違いが草丈の違い の原因であると予想される。生徒実験として行なっ ていない GA 合成阻害剂投与実験を参考資料として 提示していれば, 生徒の考察の助けとなったと考え られる。事前に品種間の遺伝子の差異について指導 者が言及しなかったにもかかわらず，80\%の生徒 が品種間で GA の生産量に違いがあることを指摘し 


\section{表 5 授業に対する評価問題とその回答率（\%）の変化及び McNemar 検定の結果}

事前, 事後は, 生徒の選択した回答率（％）を示し, 事後における正答者数の変化について McNemar 検定を行ない, $\mathrm{X}^{2}$ 值 および 值を求めた。備考闌の※は $5 \%$ での有意差を示し, n.s. は有意差を示さないことを表す。

\begin{tabular}{|c|c|c|c|c|c|}
\hline （1）ジベレリンによっておこる茎の変化は次のうちどれか 1 つ選びなさい。 & 事前 & 事後 & $\mathrm{X}^{2}$ 值 & $p$ 值 & 備考 \\
\hline （a）茎の伸長を促進する。 & 100 & 100 & 0 & 1 & n.s. \\
\hline （b）茎の伸長を抑制する。 & 0 & 0 & & & \\
\hline (c) 茎の太さを太くする。 & 0 & 0 & & & \\
\hline （d）茎の太さを細くする。 & 0 & 0 & & & \\
\hline （e）ジベレリンによって起こる変化が分からない。 & 0 & 0 & & & \\
\hline （2）ジベレリンによる茎に生じる変化について正しい記述を全て選びなさい。 & 事前 & 事後 & $\mathrm{X}^{2}$ 值 & $p$ 值 & 備考 \\
\hline (a) ジベレリンを与えると 1～2 日で変化する。 & 52 & 67 & 3 & 0.083 & n.s. \\
\hline （b）ジベレリンを与えると 4〜 5 日で変化する。 & 10 & 24 & & & \\
\hline （c）変化し続けるにはジベレリンを与え続けなくてはいけない。 & 19 & 5 & & & \\
\hline （d）ジベレリンを 1 度与えるとその効果はしばらく続く。 & 62 & 86 & 5 & 0.025 & ※ \\
\hline （e）ジベレリンが茎に対して，いつどのようにして働くかは，分からない。 & 24 & 5 & & & \\
\hline （3）ヒマワリの品種の差とジベレリンの関係について正しいものを全て選びなさい。 & 事前 & 事後 & $\mathrm{X}^{2}$ 值 & $p$ 值 & 備考 \\
\hline （a）通常品種はジベレリンの合成能力が高いので, 背が高くなる。 & 62 & 86 & 5 & 0.025 & $※$ \\
\hline （b）通常品種はジベレリンの合成能力が低いので, 背が高くなる。 & 14 & 5 & & & \\
\hline （c）矮性品種はジベレリンの合成能力が高いので, 背が低くなる。 & 14 & 10 & & & \\
\hline （d）矮性品種はジベレリンの合成能力が低いので，背が低くなる。 & 57 & 86 & 5 & 0.025 & $※$ \\
\hline (e) ヒマワリの品種の差とジベレリンの関係について，分からない。 & 14 & 0 & & & \\
\hline （4）植物ホルモンの働き方について正しく述べているものを1つ選びなさい。 & 事前 & 事後 & $\mathrm{X}^{2}$ 值 & $p$ 值 & 備考 \\
\hline （a）植物ホルモンは，植物自身が作るものしか効果が無い。 & 0 & 0 & & & \\
\hline $\begin{array}{l}\text { (b) 植物ホルモンは, 植物の体内で働くので, 植物の体に塗ったりかけたりして } \\
\text { も効果が無い。 }\end{array}$ & 10 & 0 & & & \\
\hline （c）植物ホルモンは, 植物の種類に関倸なく効果を示す。 & 24 & 29 & 0.33 & 0.56 & n.s. \\
\hline （d）植物ホルモンは，特定に器官に対して特定の効果のみを生じる。 & 57 & 71 & & & \\
\hline （e）植物ホルモンの働き方について正しく述べられている文を判断できない。 & 5 & 0 & & & \\
\hline （5）植物ホルモンの効果について正しく述べているものを全て選びなさい。 & 事前 & 事後 & $\mathrm{X}^{2}$ 值 & $p$ 值 & 備考 \\
\hline （a）サイトカイニンによって, 落葉を促進する。 & 10 & 14 & & & \\
\hline （b）オーキシンは，頂芽優勢を引き起こす原因となっている。 & 71 & 62 & 0.67 & 0.4 & n.s. \\
\hline （c）エチレンによって，発芽が促進される。 & 19 & 14 & & & \\
\hline (d) アブシシン酸によって，気孔が開く。 & 5 & 24 & & & \\
\hline （e）ジベレリンによって種なしブドウが生産される。 & 76 & 95 & 4 & 0.046 & ※ \\
\hline
\end{tabular}

た（図 7)。品種間の形質の差を遺伝子の差異ととら えた生徒は $20 \%$ 未満に止まったが, GA の生産量や 遺伝子の違いを調べるために遺伝子操作を提案する 意見は，無回答が多かった設問にも関わらず，20\% に達した。この実践を通して, バイオテクノロジー の単元での学習内容を活用した生徒がいたと考えら れる。

実験後の感想の欄には，「GA が成長を促進するの は勉強したので知っていましたが，どのくらい成長 するのは知りませんでした。最初は促進するといっ てもおまけ程度だと思っていましが, 今回の実験で 結構することがわかりました」。や「花壇の土と混ぜ る肥料にたくさんの栄養が詰まっていて, 花はそれ を吸収して大きくなると考えていましたが，今回の
実験で植物が成長するのに必要なのは肥料だけじゃ ないということがわかりました。」など実験を通して 理解できるようになったことも多く述べていた。以 上のように，本教材を利用することで GA の作用を はっきりと理解するようになったことは，評価問題 の正答率の変化からもうかがえ，また，植物の成長 に関し感覚的に理解していた事柄を，植物ホルモン の作用という観点で改めて理解するのに役立ったと 言える。

\section{5. おわりに}

矮性品種と高性品種のヒマワリの茎の伸長に対す る GAの効果を調べる教材を開発し，実践授業を行 なった。1 週間程度の短い期間の観察で, GA が茎の 
伸長を促進させることを確かめることができた。植 物の栽培が小学生以来だと楽しそうに話しながら作 業をしたり，日々大きく成長するヒマワリの姿に愛 着を持って観察したりする姿が印象的であった。こ の実験のような体験こそが知識の定着には不可欠な 要素であると感じた。単純な長さの測定という活動 であるが, $\mathrm{GA} の$ 投与時期を変えることや GA 合成 阻害剂と合わせて使用するなど様々な工夫も考えら れる。また, 遺伝子との関連を気付きは一部の生徒 だったので, 気付かせる工夫も今後の課題である。

\section{引用文献}

浅島誠・他 20 名 (2013) 『生物』東京書籍

Fambrini, M., Mariotti, L., Parlanti, S., Picciarelli, P., Salvini, M., Ceccarelli, N., \& Pugliesi, C. (2011). The extreme dwarf phenotype of the GAsensitive mutant of sunflower, dwarf2, is generated by a deletion in the ent-kaurenoic acid oxidase1 (HaKAO1) gene sequence. Plant Mol. Biol., 75, 431-450.

本川達雄・他 17 名 (2013) 『生物』啓林館

本川達雄 - 他 19 名 (2006) 『高等学校改訂版生物 I』啓林館

石原勝敏・他 14 名 (2009) 『新版生物 I 』実教出版

石川統・他 19 名 (2008) 『生物 I』東京書籍

Katagi, T., Mikami, N., Matsuda, T., \& Miyamoto, J. (1987). Structural studies of the plant growth regulator uniconazole (ES pure) and computer-aided analysis of its interaction with cytochrome P-450. J. Pesticide Sci., 12, 627-633.
川嶋誠一郎 - 他 9 名 (2011) 『改訂版高等学校生物 I』数研 出版

Marchant, R.B., Casimiro, I., Eklöf, J., Casero, P.J., Bennett, M., \& Sandberg, G. (2002). AUX1 promotes lateral root formation by facilitating indole-3-acetic acid distribution between sink and source tissues in the Arabidopsis seedling. Plant Cell, 14, 589-597.

文部科学省 (2009) 『高等学校学習指導要領解説 理科編 理数編』実教出版, 89-90.

文部省 (1999) 『高等学校学習指導要領解説 理科編 理数 編』大日本図書, 131-135.

Peng, J., Carol, P., Richards, D.E., King, K.E., Cowling, R.J., Murphy, G.P., \& Harberd, N.P. (1997). The Arabidopsis GAI gene defines a signaling pathway that negatively regulates gibberellin responses. Genes. Dev., 11, 3194-3205.

嶋田和正・他 21 名 (2013) 『生物』数研出版 庄野邦彦・他 13 名 (2014) 『生物』実教出版 田中隆荘 - 他 22 名 (2009) 『高等学校改訂生物 I』第一学 習社.

山路裕昭・古賀雅夫 ·星野由雅・中西弘樹 · 近藤宽 (2006) 高等学校理科における観察, 実験の現状について『長 崎大学教育学部紀要 (教科教育学)』第 46 巻, 77-86. 山根久和（1991）植物ホルモンと矮性 化学と生物. 第 29 卷, 第 5 号, 330-336.

吉里勝利・他 16 名（2013）『高等学校生物』第一学習社.

(2016 年 5 月 11 日受付, 2017 年 1 月 24 日受理) 


\title{
Development of Teaching Material Using Dwarf Sunflower plants for Understanding the Effect of Gibberellin on Stem Elongation
}

\author{
Hiroshi SONOYAMA ${ }^{1}$, Shigeaki ATSUMI ${ }^{2}$ \\ ${ }^{1}$ Kyoto Prefectural Yamashiro High School \\ ${ }^{2}$ Hyogo University of Teacher Education
}

\begin{abstract}
SUMMARY
Seedlings of the dwarf sunflower 'konatsu' were approximately $20 \%$ as tall as the tall 'kagayaki' type 12 days after seeding. However, when gibberellic acid (GA) $\left(1.0 \times 10^{-4} \mathrm{M} \mathrm{GA}_{3}\right)$ was applied 5 days after seeding, the dwarf sunflower seedlings became elongated, up to twice as tall as the control plants. The dwarf sunflower seedlings treated with GA elongated at the rate of $7.6 \mathrm{~mm} / \mathrm{day}$, while the elongation rate of the tall ones was $8.0 \mathrm{~mm} /$ day. That is, the dwarf sunflower seedlings could recover their height through the GA treatment. Based on these results, we developed a lesson in which students sprayed a dose of gibberellic acid solution on sunflower seedlings and measured the elongation of the seedlings for one week. The students plotted a graph of the seedling elongation and compared the heights of the tall sunflower seedlings with those of the dwarf ones, and also compared the height of the GA treated seedlings with those of the untreated ones with the aid of a worksheet. To clearly evaluate our lesson, the achievement tests of students' understanding of the plant hormone GA and the plant's morphology were carried out before and after the lesson. They revealed that the students' correct answers on the relationship between gibberellin and height of the seedlings increased from $57 \%$ to $86 \%$. Furthermore, approximately $95 \%$ of the students stated that their interest in the mechanism of the plant growth was aroused. Asking them about the comprehensive approach to the resolution of the relationship between plant growth and GA, some students proposed a quantificational experiment using endogenous GA contents and other students offered a comparison of the participant plants' genes. These replies suggested that they came to consider the difference in the GA contents as well as variations in genes among the sunflower varieties.
\end{abstract}

$<$ Key words $>$ dwarf, gibberellin, sunflower, experimental teaching materials 